Available online at http://jurnal.goretanpena.com/index.php/JSSR

\title{
SISTEM PAKAR METODE CERTAINTY FACTOR DALAM DIAGNOSA PENYAKIT KANKER KELENJAR GETAH BENING PADA RSUD H. ABDUL MANAN SIMATUPANG
}

\author{
Juna Eska ${ }^{1}$, Hidayatullah ${ }^{2}$, Hambali $^{3}$ \\ STMIK Royal, Kisaran \\ e-mail: ${ }^{1}$ dosenjunaeska@gmail.com
}

\begin{abstract}
Lymph node cancer is also known as lymphoma cancer, which is blood cancer in the lymphatic system which causes enlargement of lymph nodes. Expert systems are computer programs that mimic an expert's reasoning with expertise in a particular area of knowledge. Expert systems try to find solutions, provide suggestions or conclusions that are consistent with the problems they find. One of the implementations of an expert system in the health sector is the expert system for diagnosing leprosy and the mediation using the Certainty factor method. Certainty Factor is a method that defines a measure of certainty against a fact or rule, to describe the level of expert belief in the problem at hand. This study will be designed using Visual Studio 2010 Applications and Desktop programming languages, as well as Sql Server 2008 databases., this system can help the community in diagnosing leprosy. Through this application, users can consult with the system like consulting an expert to diagnose symptoms that occur in users and find solutions to problems faced.
\end{abstract}

Keywords: Expert System, Lymph Gland Cancer, Certainty factor

\begin{abstract}
Abstrak: Kanker kelenjar getah bening dikenal juga dengan istilah kanker limfoma, yaitu kanker darah dalam sistem limfatik yang menyebabkan pembesaran kelenjar getah bening. Sistem pakar adalah program komputer yang menirukan penalaran seorang pakar dengan keahlian pada suatu wilayah pengetahuan tertentu. Sistem pakar mencoba mencari solusi, memberikan saran atau kesimpulan yang konsisten terhadap permasalahan yang ditemukannya. Salah satu implementasi yang diterapkan sistem pakar dalam bidang kesehatan yaitu sistem pakar untuk melakukan diagnosa penyakit kusta dan pencengahannya menggunakan metode Certainty factor. Certainty Factor atau faktor kepastian merupakan metode yang mendefenisikan ukuran kepastian terhadap suat fakta atau aturan, untuk menggambarkan tingkat keyakian pakar terhadap masalah yang sedang dihadapi.Penelitian ini akan dirancang menggunakan Aplikasi Visual Studio 2010 dan bahasa pemrograman Desktop, serta database Sql Server 2008. Harapan penulis, sistem ini dapat membantu masyarakat dalam mendiagnosa penyakit kusta. Melalui aplikasi ini, pengguna dapat melakukan konsultasi dengan sistem layaknya berkonsultasi dengan seorang pakar untuk mendiagnosa gejala yang terjadi pada pengguna serta menemukan solusi atas permasalahan yang dihadapi.
\end{abstract}

Kata kunci: Sistem Pakar, Kanker Kelenjar Getah Bening, Certainty factor.

\section{PENDAHULUAN}

Seiring perkembangan teknologi yang sangat pesat, pada bidang kedokteran saat ini juga telah menfaatkan teknologi untuk membantu peningkatan pelayanan yang lebih baik kepada masyarakat luas. Pekerjaan yang sangat sibuk dari seorang dokter mengakibatkan bidang sistem pakar mulai dimanfaatkan untuk membantu seorang pakar/ahli dalam mendiagnosa berbagai macam 
Available online at http://jurnal.goretanpena.com/index.php/JSSR

penyakit, seperti asma, jantung, ginjal, stroke, kanker, gigi, kulit hingga ke mata. Semua itu didukung oleh kemajuan teknologi informasi dengan komputer sebagai alat bantu dalam pengolahan datanya (Simangunsong,dkk. 2017).

Sistem pakar (Expert System) adalah program berbasis pengetahuan yang menyediakan solusi-solusi dengan kualitas pakar untuk masalah-masalah dalam domain yang spesifik. Implementasi sistem pakar banyak digunakan dalam bidang kesehatan karena sistem pakar dipandang sebagai cara penyimpanan pengetahuan pakar pada bidang tertentu dalam program komputer sehingga keputusan dapat diberikan dalam melakukan penalaran secara cerdas (Raharjo,dkk. 2016).

Kecerdasan buatan (Artificial Inteligent) merupakan bagian dari ilmu komputer yang membuat agar mesin (komputer) dapat melakukan pekerjaan yang dilkukan oleh manusia. Sistem cerdas adalah sistem yang dibangun dengan menggunakan teknik-teknik kecerdasan buatan.

Salah satu pada kecerdasan buatan adalah teori kepastian menggunakan metode certainty factor. Faktor kepastian (Certainty Factor) menyatakan kepercayaan dalam sebuah kejadian (fakta atau hipotesis) berdasarkan bukti atau penilaian pakar. Contohnya seorang dokter seringkali menganalisa informasi yang ada dengan ungkapan seperti mungkin, kemungkinan besar, hampir pasti. Oleh sebab itu menggunakan metode Certainty Factor guna menggambarkan tingkat keyakinan pakar terhadap permasalahann yang sedang dihadapi(Mariana,dkk.2017). Penelitian terdahulu metode Certainty Factor menurut Stephanie Halim dan Seng Hansun pada jurnal yang berjudul "Penerapan Metode Certainty Factor dalam Sistem Pakar Pendeteksi Resiko Osteoporosis dan Osteoarthritis" menyediakan sebuah aplikasi sistem pakar mendeteksi resiko penyakit osteoporosis dan osteoarthritis. Dengan presentasi keakuratan $80 \%$ menjadi bukti nyata bahwa diagnosa gejala setiap pakar mempengaruhi tingkat keakuratan sistem (Arifin,dkk.2017).

Salah satu implementasi yang diterapkan sistem pakar dalam bidang kesehatan yaitu sistem pakar untuk melakukan diagnosa penyakit kanker kelenjar getah bening dan pencegahannya menggunakan metode certainty factor. Penulis melakukan penelitian pada RSUD H. Abdul Manan Simatupang Kisaran dalam mendiagnosa penyakit kanker kelenjar getah bening. Kanker kelenjar getah bening dikenal juga dengan istilah kanker limfoma, yaitu kanker darah dalam sistem limfatik yang menyebabkan pembesaran kelenjar getah bening. Dilansir dari Cancer Treatment Centers of America, ada lebih dari 500 kelenjar getah bening di seluruh tubuh manusia, semuanya terhubung melalui jaringan pembuluh getah bening. Kelompok kelenjar getah bening dapat ditemukan di leher, ketiak, selangkangan, perut, panggul dan dada.

Kelenjar getah bening bersirkulasi di sel darah putih. Ketika konsentrasi sel darah putih meningkat sebagai bagian dari respons kekebalan tubuh terhadap virus atau infeksi, kelenjar getah bening bisa membengkak. Dalam beberapa kasus, pembengkakan disebabkan oleh kondisi lain, seperti kanker. Kanker kelenjar getah bening disebabkan karena sel-sel melawan infeksi sistem kekebalan tubuh, yang disebut limfosit. Sel-sel ini berada di kelenjar getah bening, limpa, timus, sumsum tulang, dan bagian tubuh lainnya. Gejala kanker getah bening bisa berupa pembengkakan kelanjar getah bening di leher, ketiak, atau selangkangan. Kemudian reaksi batuk, sesak napas, demam, berkeringat di malam hari, sakit perut, kelelahan, berat badan turun, dan gatal-gatal. Untuk kemampuan analisa yang tepat dan akurat merupakan hal yang penting yang diperlukan dalam 
Available online at http://jurnal.goretanpena.com/index.php/JSSR

melakukan diagnosa apakah seseorang menderita penyakit kanker kelenjar getah bening atau tidak, sehingga dapat memperkecil resiko kesalahan dalam proses diagnosa pada umumnya. Penelitian ini dilakukan di RSUD $\mathrm{H}$. Abdul Manan Simatupang, data yang diperoleh dari rumah sakit berupa data jumlah pasien penyakit kelenjar getah bening 5 tahun terakhir. Rincian dari jumlah pasien penyakit kaki gajah dilihat pada tabel 1.1 ini sebagai berikut:

Tabel 1.1 Data Jumlah Pasien Penyakit Kelenjar Getah Bening

\begin{tabular}{|c|c|}
\hline Tahun & Jumlah Pasien/Tahun \\
\hline 2014 & 40 orang \\
\hline 2015 & 46 orang \\
\hline 2016 & 54 orang \\
\hline 2017 & 40 orang \\
\hline 2018 & 32 orang \\
\hline TOTAL & 212 orang \\
\hline
\end{tabular}
Manan Simatupang

Dalam penelitian ini akan di rancang sebuah sistem pakar yang nantinya akan membantu dokter spesialis penyakit dalam dan paramedis dalam mengambil keputusan tentang penyakit apa yang diderita oleh pasien berdasarkan masukan yang diberikan pada sistem. Sistem pakar ini akan membantu RSUD H. Abdul Manan Simatupang Kisaran dalam diagnosa penyakit kanker kelenjar getah bening apakah pasien mengalami penyakit tersebut atau tidak, dan tidak perlu menggunakan waktu yang cukup lama dalam pemeriksaan sehingga dokter dan paramedis dapat memberikan solusisolusi yang harus dilakukan oleh pasien dalam mengatasi penyakit yang diderita pasien secara tepat dan akurat.

\section{Sistem Pakar}

Sistem pakar adalah sistem yang didesain dan di implementasikan dengan bantuan bahasa pemrogramana tertentu untuk dapat menyelesaikan maslah seperti yang dilakukan oleh para ahli (Syahromi, 2016), sedangkan menurut Arhami
(2017), sistem pakar adalah sebuah teknik inovatif baru dalam menangkap dan memadukan pengetahuan, kekuatan sistem pakar terletak pada kemampuannya memecahkan masalah-masalah praktis pada saat seorang pakar berhalangan. Kemampuan sistem pakar ini didalamnya terdapat basis pengetahuan yang berupa pengetahuan non formal yang sebagian besar dari pengalaman.

\section{Klasifikasi Sistem Pakar}

Berdasarkan struktur program klasifikasi sistem pakar dibagi menjadi beberapa bagian yaitu : Diagnosis, Pengajaran, Interpretasi, Prediksi, Perencanaan dan Kontrol. (Andriyanto. 2018)

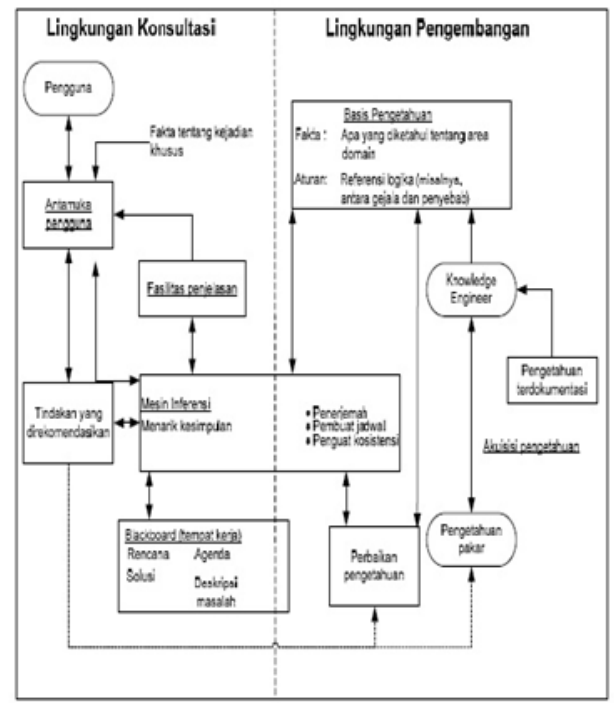

\section{Gambar Arsitektur Sistem Pakar Sumber: Andriyanto \& Santoso}

\section{Ciri-ciri Sistem Pakar}

Dalam pengetahuan sistem pakar terdapat ciri-ciri sebagai berikut (Syahromi, 2016) :

a.

Dapat memberikan penalaran untuk data-data yang tidak pasti.

b. Dapat mengemukakan serangkaian alasan yang diberikan dengan cara yang dapat dipahami. 
Available online at http://jurnal.goretanpena.com/index.php/JSSR

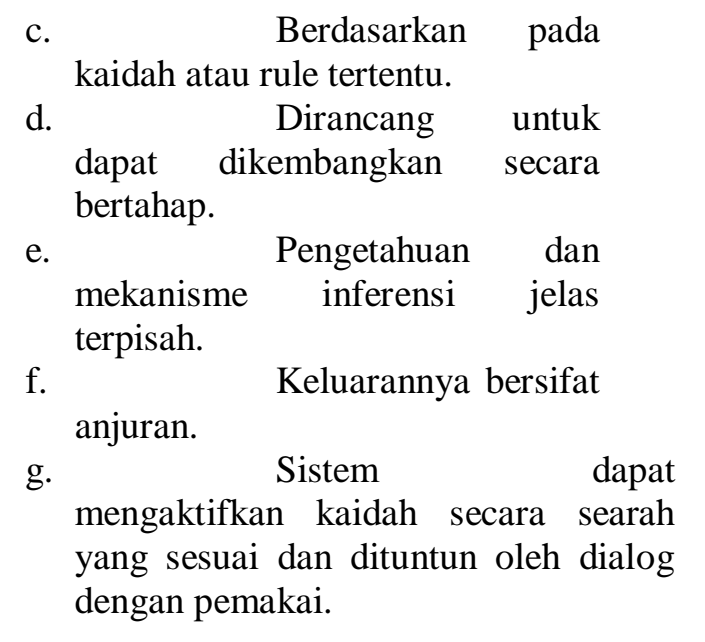

\section{Komponen-komponen Sistem Pakar}

Komponen-komponen dalam pengembangan sistem pakar terdiri dari beberapa bagian diantaranya : Basis Pengetahuan (Knowledge Base), Basis Data (Data Base), Mesin Inferensi (Inference Engine), Antar Muka Pemakai (User Interface) (Arhami, 2017).

\section{Basis Pengetahuan (Knowledge Base)}

Basis pengetahuan merupakan inti program sistem pakar dimana basis pengetahuan ini merupakan representasi pengetahuan dari seorang pakar. Pengetahuan representasi ini seperti faktafakta, aturan-aturan atau prosedur serta pengetahuan heuristik yang tersedia dalam system (Arhami, 2017). Perancangan bentuk representasi pengetahuan mempengaruhi rancangan unference engine proses, updating pengetahuan, dan efisiensi sistem secara keseluruhan. Penalaran pada knowledge base terbagi menjadi 2 :

a) Penalaran berbasis aturan

b) Penalaran berbasis kasus

\section{Basis Data (Data base)}

Basis data adalah bagian yang mengandung semua fakta-fakta, baik fakta awal pada saat sistem mulai beroperasi maupun fakta-fakta yang diambil pada saat ketika proses sedang berjalan (Arhami, 2017). Pada hakekatnya sistem pakar banyak mengandung suatu basis data untuk menyimpan hasil penelitian dan data lainnya yang dibutuhkan selama pengelolaan.

$\begin{array}{ccc}\text { Menurut } & \text { Raharjo } & (2015: 2) \\ \text { mengatakan } & \text { bahwa } & \text { database }\end{array}$
didefenisikan sebagai kumpulan data yang terintegrasi dan diatur sedemikian rupa sehingga data tersebut dapat dimanipulasi, diambil dan dicari secara cepat.

\section{Certainty Factor}

Certainty Factor atau faktor kepastian menyatakan kepercayaan dalam sebuah kejadian (fakta atau hipotesis) berdasarkan bukti atau penilaian pakar. Faktor kepastian diperkenalkan untuk mengakomodasi ketidakpastian pemikiran seorang pakar (Mariana, 2012:152). Contohnya seorang dokter seringkali menganalisa informasi yang ada dengan ungkapan seperti mungkin, kemungkinan besar, hampir pasti. Oleh sebab itu menggunakan metode Certainty Factor guna menggambarkan tingkat keyakinan pakar terhadap permasalahann yang sedang dihadapi (Puspitasari, 2012:1). Certainty factor didefenisikan sebagai berikut (Hartanti,2016:103):

$\mathrm{CF}(\mathrm{H}, \mathrm{E}) \quad=\mathrm{MB}(\mathrm{H}, \mathrm{E})-\mathrm{MD}(\mathrm{H}, \mathrm{E})$

Dimana:

$\mathrm{CF}(\mathrm{H}, \mathrm{E})=$ Certainty factor hipotesis $\mathrm{H}$ yang dipengaruhi oleh evidence (gejala) $\mathrm{E}$ $\mathrm{MB}(\mathrm{H}, \mathrm{E})=$ ukuran kepercayaan (measure of increased belief) terhadap hipotesis $\mathrm{H}$ yang dipengaruhi oleh evidence $\mathrm{E}$ $\mathrm{MD}(\mathrm{H}, \mathrm{E})=$ ukuran ketidakpercayaan (measure of increased disbelief) terhadap hipotesis $\mathrm{H}$ yang dipengaruhi oleh evidence $\mathrm{E}$

Di dalam MYCIN terdapat aturan untuk menggabungkan evidence anteseden yang terdapat dalam sebuah kaidah. Hal ini dapat dilihat pada tabel

Tabel Kombinasi Evidence Anteseden

\begin{tabular}{|l|l|}
\hline EVID & NILAI \\
ENCE & KEPASTIAN \\
\hline E1 ang & Min[(CF(HE1), \\
\hline
\end{tabular}


Available online at http://jurnal.goretanpena.com/index.php/JSSR

\begin{tabular}{|l|l|}
\hline E2 & $\mathrm{CF}(\mathrm{CF}, \mathrm{E} 2)]$ \\
\hline E1 or & $\mathrm{Max}[(\mathrm{CF}(\mathrm{HE} 1)$ \\
E2 & $, \mathrm{CF}(\mathrm{CF}, \mathrm{E} 2)]$ \\
\hline Not E & $-\mathrm{CF}(\mathrm{H}, \mathrm{E})$ \\
\hline
\end{tabular}

Berikut ini diberikan contoh untuk mengkombinasikan evidence: $\mathrm{E}=(\mathrm{E} 1 \mathrm{AND}$ E2 AND E3) OR (E4 AND NOT E5)

Besarnya nilai kepastian untuk gejala $\mathrm{E}$ akan dihitung sebagai berikut:

Cf untuk gejala $\mathrm{E}=$ [min(E1,E2,E3), $\min (\mathrm{E} 4, \mathrm{E} 5)]$

Dimana nilai :

$$
\begin{aligned}
& \mathrm{E} 1=0.9 \quad \mathrm{E} 2=0.8 \text { E3=0.3 E4=-0.5 E5=- } \\
& 0.4
\end{aligned}
$$

Sehingga nilai $\mathrm{CF}$ untuk gejala $\mathrm{E}$ adalah :

$\mathrm{CF}$ gejala $\mathrm{E}=\max [\min (0.9,0.8,0.3)$, $\min (-0.5,-(-0.4))]$

$\min (-0.5,-0.4)]$

$=\max [\min (0.9,0.8,0.3)$,

$$
=\max [0.3,-0.5]
$$$$
=0.3
$$

Bentuk dasar rumus Certainty factor sebuah aturan dalam bentuk if $\mathrm{E}$ then $\mathrm{H}$ adalah sebagai berikut :

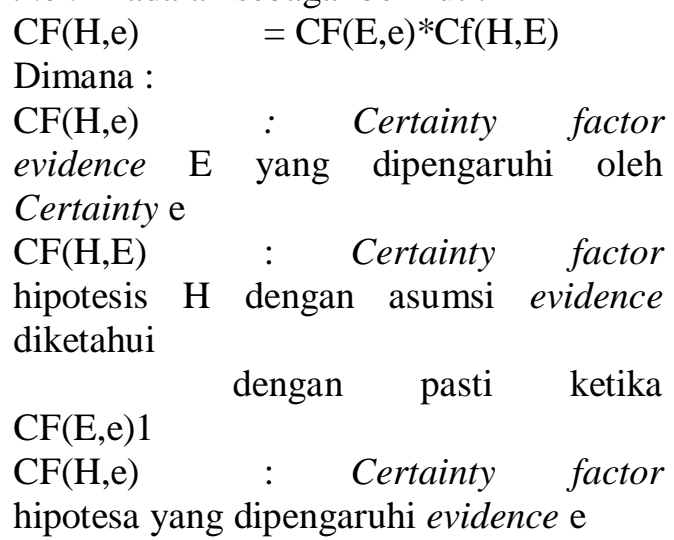

\section{METODE}

Dalam penelitian ini metode yang digunakan adalah penelitian kualitatif. Penelitian kualitatif adalah sebuah cara/upaya lebih untuk menentukan pada aspek pemahaman secara mendalam pada suatu permasalahan. Tujuan dari metode ini adalah pemahaman secara luas dan mendalam terhadap suatu permasalahan yang sedang di kaji atau yang akan di kaji. Metode ini digunakan karena penelitian ini berinteraksi langsung pada RSUD H. Abdul Manan Simatupang dan peneliti langsung melakukan pengamatan, mencatat, mencari tahu serta menggali sumber tentang informasi mengenai penyakit kanker kelenjar getah bening.

\section{Teknik Pengumpulan Data}

Pengumpulan data dan informasi pada tahap ini dilakukan untuk mengetahui mengenai sistem yang diteliti. Dari data dan informasi yang dikumpulkan akan didapat data untuk pendukung penelitian, diperoleh melalui informasi internet dan wawancara langsung dengan dokter yang ahli dalam untuk mendapatkan data, adapun teknik pengumpulan data tersebut adalah:

1. Wawancara (Interview)

Penulis melakukan proses tanya jawab atau wawancara kepada narasumber secara langsung untuk memperoleh data atau informasi yang diperlukan untuk menyusun skripsi ini.

2. Pengamatan (Observasi)

Metode ini dilakukan dengan cara mencari data melalui pengamatan di lapangan atau terjun langsung ke RSUD HAMS Kisaranmengamati objek yang akan diteliti. Kemudian mencatat hal-hal yang penting yang berhubungan dengan penulisans skripsi yang sedang diolah.

3. Studi Pustaka

Penulis melakukan penelitian dengan cara mempelajari dan membaca literatur-literatur yang ada hubungannya dengan permasalahan yang menjadi objek penelitian.

\section{HASIL DAN PEMBAHASAN}

Setelah melaui proses perancangan dan implementasi dari datadata yang diperoleh melalui pengumpulan data sebelumnya dihasilkan sebuah aplikasi Sistem Pakar Metode Certainty 
Available online at http://jurnal.goretanpena.com/index.php/JSSR

Factor Dalam Diagnosa Penyakit Kanker Kelenjar Getah Bening

\section{Tampilan Form Login}

Form login berisi tombol yang dibutuhkan seperti tombol login. Berikut ini adalah tampilan form login:

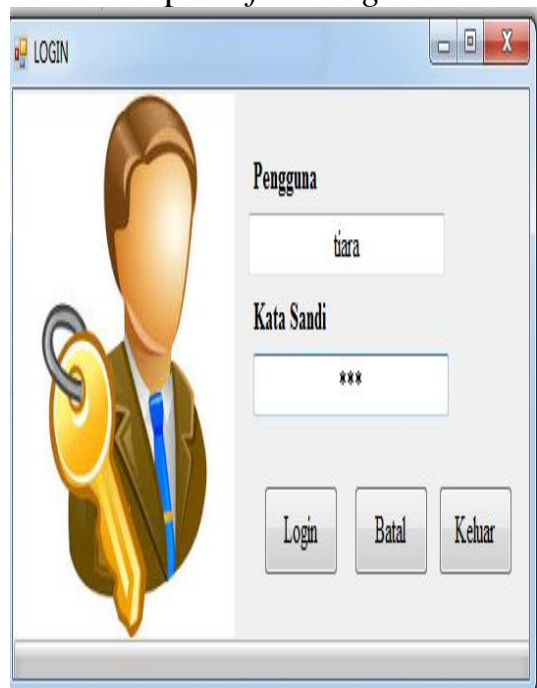

Gambar Tampilan Form Login

\section{Tampilan Input dan Tampil Data} Pasien

Input data pasien berfungsi sebagai salah satu penentuan kelayakan penerimaan data pasien diagnosa penyakit kelenjar getah bening:

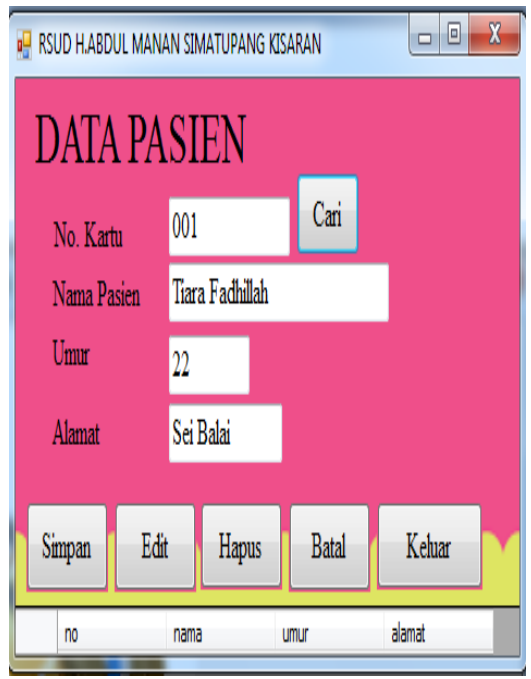

Gambar Tampilan Input Data Pasien

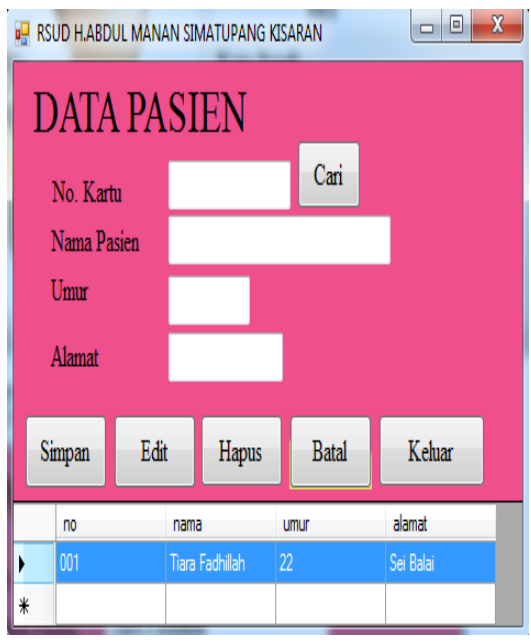

Gambar Tampilan Data Pasien

\section{Tampilan Input dan Tampil Data} Konsultasi

Input data konsultasi berfungsi sebagai salah satu penentuan diagnosa penyakit kelenjar getah bening seperti simpan, edit, hapus, cari, dan batal. Berikut adalah tampilan input data konsultasi:

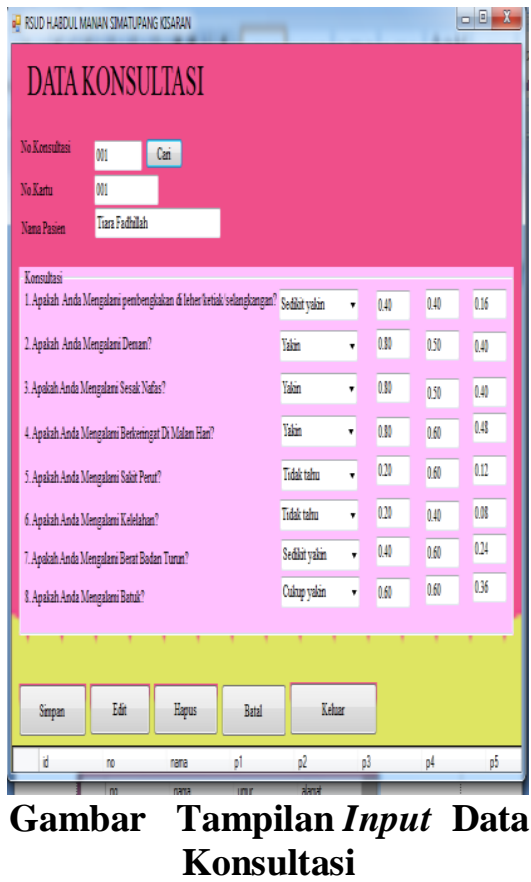


Available online at http://jurnal.goretanpena.com/index.php/JSSR

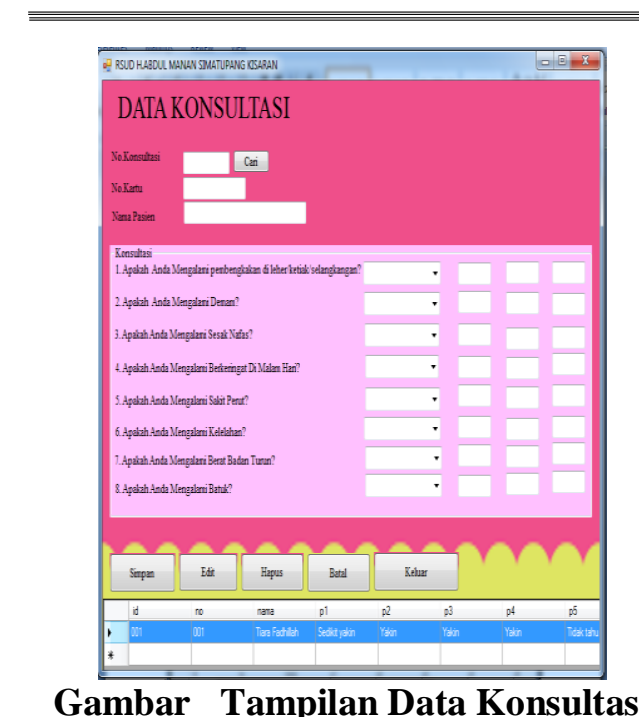

\section{Tampilan Input dan Tampil Data Hasil Diagnosa}

Input data hasil diagnosa berfungsi sebagai salah satu penentuan diagnosa penyakit kelenjar getah bening seperti simpan, edit, hapus, cari, dan batal. Berikut adalah tampilan input data hasil diagnosa:

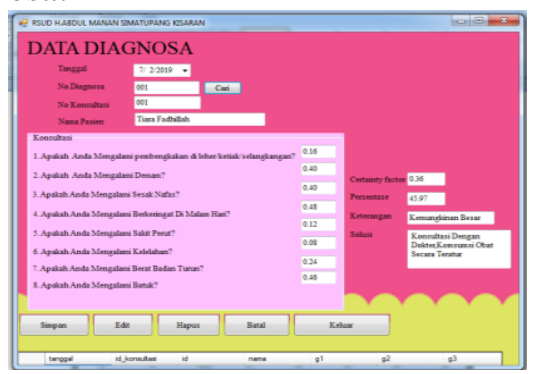

\section{Gambar Tampilan Input Data Hasil Diagnosa}

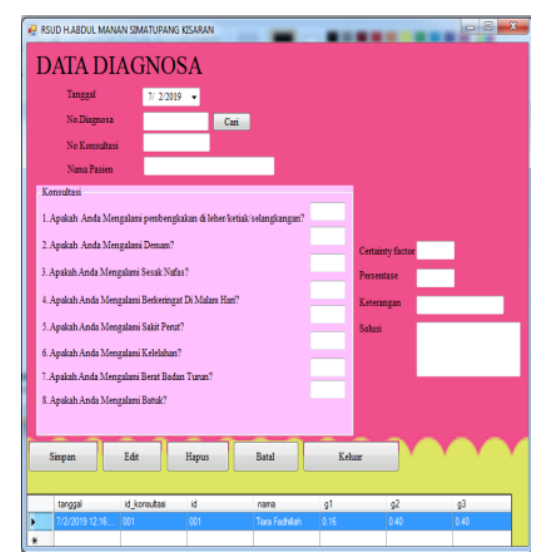

Gambar Tampilan Data Hasil Diagnosa

\section{SIMPULAN}

1.sistem ini dapat mempermudah pakar pada RSUD. H. Abdul Manan Simatupang dalam pengolahan proses gejala, pencarian dan pembuatan laporan data diagnosa penyakit kelenjar getah bening pada RSUD. H. Abdul Manan Simatupang.

2.Sistem pakar ini tidak berarti menggantikan kedudukan dokter, tetapi hanya membantu dalam mengkonfirmasikan keputusannya dan mempermudah dalam pengambilan keputusan, karena mungkin bisa terdapat banyak alternatif yang harus dipilih secara tepat.

3. Dengan adanya sistem pakar yang telah dibuat menggunakan metode Certainty Factor dapat membantu proses diagnosa penyakit kelenjar getah bening pada RSUD. H. Abdul Manan Simatupang.

4.Program aplikasi yang digunakan dalam merancang sistem pakar diagnosa penyakit kelenjar getah bening pada RSUD. H. Abdul Manan Simatupang adalah Microsoft Visual Studio 2010 dan database Sql Server 2008.

5.ada informasi hasil pengujian atas, didapatkan hasil akurasi manual dan dengan software akurasi $100 \%$ sehingga menggunakan cara ini akan lebih mempermudah diagnosa penyakit kelenjar getah bening pada RSUD. H. Abdul Manan Simatupang

\section{DAFTAR PUSTAKA}

Arhami. (2017). Konsep Sistem Pakar. Yogyakarta: Andi Offset 
Available online at http://jurnal.goretanpena.com/index.php/JSSR

Andryanto, I. (2018). Pemodelan Sistem pakar Untuk Menentukan Penyakit Diabetes Melitus Menggunakan Metode Nayve Bayes. Jurnal Pengembangan Teknologi Informasi dan Ilmu Komputer, 2:880-887

Hartati, S. (2016). Sistem Pakar Dan Pengembangannya.Yogyakart a:Graha Ilmu

Herpendi. (2016). Aplikasi Pengelolaan Nilai Akademik Mahasiswa dan DPNA. Jurnal Sains Teknologi, 2 :1-6

Hutahaean, J. (2013). Konsep Sistem Informasi. Yogyakarta: Deepublish

Kusrini. (2017). Sistem Pakar Teori dan Aplikasi. Yogyakarta: Andi Offset

Mariana, N. (2012). Penerapan Model Certainty factor Untuk Mendeteksi Gejala Kanker Mulut Rahim. Jurnal Teknologi Informasi Dinamik, 20:42-50

Nurkholis, A. (2017). Sistem Pakar Penyakit Lambung Menggunakan Metode Forward Chaining. Jurnal Ilmiah, 13:32-38
Rosa, M. S. (2012). Rekayasa Perangkat Lunak. Yogyakarta:Andi

Offset.

Ritonga, NA. (2015). Sistem pakar Mendiagnosa Penyakit Lambung Menggunakan Metode Certainty Factor Berbasis Web dan Mobile. Jurnal Pelita Informatika Budi Darma, 5:157-161

Syahromi, P. (2016). Sistem pakar Mendiagnosa Penyakit Leptospirosis Menggunkan Metode Certainty factor Dengan Penelusuran Forward Chaining. Jurnal Riset Komputer, 3:108-112

Yatiman, A. (2017). Sistem pakar Mendiagnosa Penyakit Mata Menggunkan Metode Certainty factor. Jurnal Techno, 20:28-40 